Research

\title{
Limited polymorphism in Plasmodium falciparum ookinete surface antigen, von Willebrand factor A domain-related protein from clinical isolates
}

\author{
Jack S Richards*1, Nicholas J MacDonald ${ }^{2}$ and Damon P Eisen ${ }^{1}$
}

\author{
Address: ${ }^{1}$ Victorian Infectious Diseases Service, Royal Melbourne Hospital, Parkville, Victoria, Grattan St, Parkville, Victoria, 3050, Australia and \\ ${ }^{2}$ Malaria Vaccine Development Branch, NIAID, National Institutes of Health, Rockville, Maryland, USA \\ Email: Jack S Richards* - richards@wehi.edu.au; Nicholas J MacDonald - nmacdonald@niaid.nih.gov; \\ Damon P Eisen - damon.eisen@mh.org.au \\ * Corresponding author
}

Published: 05 July 2006

Malaria Journal 2006, 5:55 doi:10.1 186/1475-2875-5-55

This article is available from: http://www.malariajournal.com/content/5/l/55

(c) 2006 Richards et al; licensee BioMed Central Ltd.

This is an Open Access article distributed under the terms of the Creative Commons Attribution License (http://creativecommons.org/licenses/by/2.0), which permits unrestricted use, distribution, and reproduction in any medium, provided the original work is properly cited.
Received: 26 April 2006

Accepted: 05 July 2006

\begin{abstract}
Background: As malaria becomes increasingly drug resistant and more costly to treat, there is increasing urgency to develop effective vaccines. In comparison to other stages of the malaria lifecycle, sexual stage antigens are under less immune selection pressure and hence are likely to have limited antigenic diversity.

Methods: Clinical isolates from a wide range of geographical regions were collected. Direct sequencing of PCR products was then used to determine the extent of polymorphisms for the novel Plasmodium falciparum sexual stage antigen von Willebrand Factor A domain-related Protein (PfWARP). These isolates were also used to confirm the extent of diversity of sexual stage antigen Pfs28.

Results: PfWARP was shown to have non-synonymous substitutions at 3 positions and Pfs 28 was confirmed to have a single non-synonymous substitution as previously described.

Conclusion: This study demonstrates the limited antigenic diversity of two prospective $P$. falciparum sexual stage antigens, PfWARP and Pfs28. This provides further encouragement for the proceeding with vaccine trials based on these antigens.
\end{abstract}

\section{Background}

Development of effective Plasmodium falciparum vaccines is a global health priority with all stages of the malaria lifecycle being investigated for possible vaccine strategies [1]. Mosquito-stage vaccines aim to induce immunity to the forms of the parasite found in the mid-gut of mosquitoes: the sexual stage macro- and microgametes and the postfertilization zygotes and ookinetes. Antibodies that target antigens in these stages prevent infection in the mosquito thus breaking the transmission cycle. Since malaria trans- mission is both highly localized and focal [2], such vaccines may form a useful element as part of integrated control programmes to locally eliminate or substantially reduce transmission. They may also have a useful role in conjunction with chemotherapeutic agents to prevent drug-resistant or vaccine-escape mutants.

The P. falciparum, mosquito-stage vaccine candidate antigens include Pfs25, Pfs28, Pfs48/45, Pfs230 and the recently described, von Willebrand factor A domain- 
related protein (PfWARP) [3,4]. PfWARP (PF08_0136b) is located on chromosome 8 (GenBank: NC 004329 Region: 1221207...1222079) and encodes a 290 amino acid protein. On the basis of previous study of orthologues in Plasmodium berghei and Plasmodium gallinaceum, PfWARP is thought to be a soluble micronemal protein expressed in the late ookinete and early oocyst [5-7]. It is proposed that the von Willebrand factor A domains found in PfWARP and other malaria antigens, including circumsporozoite protein and thrombospondin-related anonymous protein have a role as an adhesive substrate and may assist in host cell invasion $[7,8]$.

Pfs28 (PF10_0302) is a lead candidate for a transmissionblocking vaccine. It is a $28-\mathrm{kDa}$ protein and is presumably anchored to parasite surface by glycosylphosphatidylinositol [9]. It is encoded on chromosome 10 and shares putative functional determinants with Pfs25. Pfs 28 is expressed on the surface of late ookinetes of $P$. falciparum and it is proposed that it is involved in adherence to the mosquito's gut epithelium [10]. Previous studies have examined Pfs 28 polymorphism in laboratory isolates Dd2, 2D11, CAMP, LE5, LF4, HB3, 7G8 [11] and from 32 field isolates from a geographically restricted region in the Philippines [12]. These have shown the presence of a single non-synonymous A274G base substitution, resulting in a conservative amino acid change from lysine to arginine (GenBank: L25843).

As part of the assessment of PfWARP's suitability as a vaccine candidate, the diversity in this gene was assessed using $P$. falciparum field isolates from a range of geo- graphic locations. In addition, Pfs 28 was sequenced in the same isolates to extend previous observations of its' diversity.

\section{Methods}

Review and approval of the study was obtained from the Research Ethics Committee of the Royal Brisbane Hospital and the Melbourne Health Human Research Ethics Committee. Clinical samples from P. falciparum-infected patients were obtained from the Malaria Reference Laboratory at the Royal Brisbane Hospital, Queensland. Twenty-two samples were studied from unrelated travellers returning from Papua New Guinea, Solomon Islands, Pakistan, Kenya, Tanzania, Uganda, Zimbabwe, and Ghana.

Whole blood specimens were stored in $8 \mathrm{M}$ guanidine hydrochloride/0.1 $\mathrm{M} \mathrm{Na} \mathrm{H}_{2} \mathrm{PO}_{4}$. Genomic DNA was isolated from the samples using the QIAquick ${ }^{\circledast}$ PCR purification kit (Qiagen, Hilden, Germany). PfWARP and Pfs 28 polymorphism was assessed using PCR conditions as outlined (Table 1). All PCR reactions used Amplitaq Gold ${ }^{\circledast}$ DNA polymerase (Roche Diagnostics, Mannheim, Germany). PCR products were detected after submarine electrophoresis using $1 \%$ agarose gel stained with ethidium bromide. PCR products were purified for direct sequencing using QIAquick ${ }^{\circledast}$ PCR purification kit (Qiagen, Hilden, Germany) or were agarose gel purified using MinElute Gel extraction kit $^{\circledast}$ (Qiagen, Hilden, Germany) purification kit. DNA sequencing was performed utilising the automated 3100 Genetic Analyser capillary system. In addition, samples with multiple infections of $P$. falciparum

Table I: Details of primers, primer and $\mathrm{MgCl}_{2}$ concentrations and cycle conditions for the amplification of PfWARP and Pfs28 genes. Oligonucleotide positions are based on NCBI Genebank sequence PfWARP (NC 004329) and Pfs28 (L25843).

\begin{tabular}{|c|c|c|c|c|}
\hline Oligonucleotide & Nucleotide sequence & Description & Primer $(\mu \mathrm{M}) / \mathrm{MgCl}_{2}(\mathrm{mM})$ & Cycle conditions \\
\hline PfWARP_USF & $\begin{array}{l}\text { GTTGTTGTATAATAAGAG } \\
\text { AGAGAAAAATG }\end{array}$ & $\begin{array}{l}\text { WARP bases }|221| 8 \mid \text { to } \\
1221209\end{array}$ & $0.6 / 2.0$ & $\begin{array}{l}94^{\circ} \mathrm{C} 10 \mathrm{~min}\left(94^{\circ} \mathrm{C} 30 \mathrm{sec}\right. \\
\left.52^{\circ} \mathrm{C} 30 \mathrm{sec}, 72^{\circ} \mathrm{C} 60 \mathrm{sec}\right) 40 \\
\text { cycles, } 72^{\circ} \mathrm{C} 5 \mathrm{~min}\end{array}$ \\
\hline PfWARP_IR & $\begin{array}{l}\text { TACATCTTATGATTTATT } \\
\text { CTTATCACATA }\end{array}$ & $\begin{array}{l}\text { WARP bases } 1222057 \text { to } \\
\text { I } 222085\end{array}$ & & \\
\hline PfWARP_IF & $\begin{array}{l}\text { GTGGTATTATGTTTTGGGT } \\
\text { ATGATATCAGC }\end{array}$ & $\begin{array}{l}\text { WARP bases } 1221222 \text { to } \\
1221250\end{array}$ & $0.6 / 1.5$ & $\begin{array}{l}94^{\circ} \mathrm{C} 10 \mathrm{~min}\left(94^{\circ} \mathrm{C} 30 \mathrm{sec},\right. \\
\left.52^{\circ} \mathrm{C} 30 \mathrm{sec}, 72^{\circ} \mathrm{C} 60 \mathrm{sec}\right) 25 \\
\text { cycles, } 72^{\circ} \mathrm{C} 5 \mathrm{~min}\end{array}$ \\
\hline PfWARP_IR & $\begin{array}{l}\text { TACATCTTATGATTTATT } \\
\text { CTTATCACATA }\end{array}$ & $\begin{array}{l}\text { WARP bases } 1222057 \text { to } \\
\text { I } 222085\end{array}$ & & \\
\hline Pfs28_FI & $\begin{array}{l}\text { ATGAATACATATTTTAAG } \\
\text { GTACTTCTT }\end{array}$ & Pfs 28 bases 60 to 86 & $1.0 / 2.5$ & $\begin{array}{l}94^{\circ} \mathrm{C} 10 \mathrm{~min}\left(94^{\circ} \mathrm{C} 60 \mathrm{sec},\right. \\
\left.46^{\circ} \mathrm{C} 60 \mathrm{sec}, 72^{\circ} \mathrm{C} 45 \mathrm{sec}\right) 40 \\
\text { cycles, } 72^{\circ} \mathrm{C} 10 \mathrm{~min}\end{array}$ \\
\hline Pfs28_R650 & $\begin{array}{l}\text { GAGCATACAATCAGAAC } \\
\text { GTGTGTTAGG }\end{array}$ & Pfs 28 bases 680 to 709 & & \\
\hline Pfs28_F40 & $\begin{array}{l}\text { CAACTTTACATAACGTTG } \\
\text { AATAAGGCTC }\end{array}$ & Pfs 28 bases 99 to 126 & $1.0 / 2.5$ & $\begin{array}{l}94^{\circ} \mathrm{C} 10 \mathrm{~min}\left(94^{\circ} \mathrm{C} 60 \mathrm{sec},\right. \\
\left.50^{\circ} \mathrm{C} 60 \mathrm{sec}, 72^{\circ} \mathrm{C} 45 \mathrm{sec}\right) 34 \\
\text { cycles, } 72^{\circ} \mathrm{C} 10 \mathrm{~min}\end{array}$ \\
\hline Pfs28_R630 & $\begin{array}{l}\text { GCATACAATCAGAACGT } \\
\text { GTGTTAG }\end{array}$ & Pfs 28 bases 666 to 689 & & \\
\hline
\end{tabular}


were detected by merozoite surface protein 2 (MSP2) PCR as previously described [13]. Amplification of this highly polymorphic gene allowed rapid detection of size separable fragments by gel electrophoresis.

\section{Results}

PfWARP was amplified from 19 of the field samples and three laboratory strains (3D7, FC27, and FCR3). As judged by MSP2 genotyping, there were multiple infections in 7 of the 19 patient samples. These 7 patient samples had a minimum of 26 genetically different clones of $P$. falciparum. However, direct sequencing of PCR products from each of these samples showed only a single genotype of PfWARP with no mixed peaks in the sequencing traces. Non-synonymous nucleotide substitutions were found to occur in three positions amongst the variant sequences. No synonymous substitutions were identified. The predicted amino acid changes were conservative and contained within the single Von Willebrand factor domain (Table 2). Sample numbers were insufficient to determine whether there was any geographic distribution to the PfWARP alleles.

Pfs 28 was amplified in 22 field samples (representing at least 31 clones due to the existence of multiple MSP2 alleles in nine patients) and in 3D7. The A274G, non-synonymous, nucleotide substitution as previously described, was found with 11 of the 22 samples having the A274 allele (Table 2). No other nucleotide substitutions were present. This data was combined with that from Hafalla et al [12] to consider the geographic distribution of Pfs 28 alleles. In Asia/Pacific isolates, 42 of 48 carried the G274 allele while only 1 of 14 of Africa/Americas isolates bore this allele ( $\mathrm{p}<0.001$, Fisher's exact test). While recognizing the size limitations of this study, it is still striking that there is such a significant difference in the geographic distribution of these Pfs 28 alleles (Table 2).

\section{Discussion}

For the first time, this study addresses the issue of antigenic diversity in PfWARP. This antigen appears to have restricted diversity with infrequent point mutations as defined. Additionally, by documenting the genotype of Pfs28 in field isolates from a larger cohort with wider geographic distribution than in previous studies, we confirm that there are only two alleles of this protein. Restricted antigenic diversity has been described in other sexual stage antigens and is explicable due to the absence of human immune selection pressure [14-16]. By contrast, asexual stage candidate antigens such as MSP2 are highly polymorphic due to $P$. falciparum's immune evasion mechanisms [17].

Pfs28, and its orthologues from other species, Pvs28 (Plasmodium vivax) and Pbs21 (P. berghei) clearly induce anti- bodies that block parasitic infection in mosquitoes and are thus candidate antigens for inducing transmission blocking immunity in humans either alone [18] or in combination with other mosquito-stage antigens. So far there have been two published vaccine trials in humans with Pfs25 [19] and with its P. vivax orthologue, Pvs25 [20], with other trials currently underway.

\section{Conclusion}

The demonstration of limited sequence variation in the newly described $P$. falciparum ookinete surface antigen PfWARP and the confirmed highly conserved nature of Pfs28 in clinical samples from a wide geographical distribution, increase the confidence that these proteins may also be suited for mosquito-stage vaccine development.

\section{Authors' contributions}

JSR carried out the genetic studies, sequence alignment and drafted the manuscript. NJM designed and supplied the primers. DPE designed a study of returned travellers with malaria and recruited the patients, assisted in the sequence alignment and helped draft the manuscript. All authors read and approved the final manuscript.

\section{Acknowledgements}

We thank the staff of the Victorian Infectious Diseases Reference Laboratory for their support. Thanks to Allan Saul for reviewing the manuscript.

Financial support: Jack Richards and Damon Eisen receive support from the Clinical Centre for Research Excellence in Infectious Diseases, Victorian Infectious Diseases Service, Royal Melbourne Hospital.

\section{References}

I. Moorthy VS, Good KF, Hill AVS: Malaria vaccine developments. Lancet 2004, 363:I50-I56.

2. Carter R: Spatial simulation of malaria transmission and its control by malaria transmission blocking vaccination. Int $J$ Parasitol 2002, 32:1617-1624.

3. Williamson KC: Pfs230: from malaria transmission-blocking vaccine candidate toward function. Parasite Immunol 2003, 25:35I-359.

4. Carter R: Transmission blocking malaria vaccines. Vaccine 200I, 19:2309-23।4.

5. Yuda M, Yano K, Tsuboi T, Torii M, Chinzei Y: von Willebrand Factor A Domain-related Protein, a novel microneme protein of the malaria ookinete highly conserved throughout Plasmodium parasites. Mol Biochem Parasitol 200 I, I I 6:65-72.

6. Li F, Templeton TJ, Popov V, Comer JE, Tsuboi T, Torii M, Vinetz JM: Plasmodium ookinete-secreted proteins secreted through a common micronemal pathway are targets of blocking malaria transmission. J Biol Chem 2004, 279:26635-26644.

7. Abraham EG, Islam S, Srinivasan P, Ghosh AK, Valenzuela JG, Ribeiro JM, Kafatos FC, Dimopoulos G, Jacobs-Lorena M: Analysis of the Plasmodium and Anopheles transcriptional repertoire during ookinete development and midgut invasion. J Biol Chem 2004, 279:5573-5580.

8. Whittaker CA, Hynes RO: Distribution and evolution of von Willebrand/integrin A domains: widely dispersed domains with roles in cell adhesion and elsewhere. Mol Biol Cell 2002, I3:3369-3387.

9. Gozar MM, Price VL, Kaslow DC: Saccharomyces cerevisiaesecreted fusion proteins Pfs 25 and Pfs 28 elicit potent Plasmodium falciparum transmission-blocking antibodies in mice. Infect Immun 1998, 66:59-64. 
Table 2: Details of PfWARP and Pfs28 polymorphisms and geographic origin for each isolate

\begin{tabular}{|c|c|c|c|c|c|}
\hline \multirow[t]{2}{*}{ Isolate number } & \multirow[t]{2}{*}{ Geographic origin ${ }^{a}$} & \multicolumn{3}{|l|}{ PfsWARP sequenceb } & \multirow{2}{*}{$\begin{array}{l}\text { Pfs } 28 \text { sequence }^{c} \\
\begin{array}{l}\text { Nucleotide sequence } \\
270-275\end{array}\end{array}$} \\
\hline & & $\begin{array}{l}\text { Nucleotide sequence } \\
\text { 1221576-1221581 }\end{array}$ & $\begin{array}{l}\text { Nucleotide sequence } \\
1221645-1221650\end{array}$ & $\begin{array}{l}\text { Nucleotide sequence } \\
\text { 1221885-1221890 }\end{array}$ & \\
\hline 3D7 & Netherlands & GTCTTT & GTAGTC & CAAACA & TTTAAA \\
\hline $\mathrm{FC} 27$ & Papua New Guinea & GTCCTT & GTATTC & CAAGCA & $X^{d}$ \\
\hline FCR3 & $\begin{array}{l}\text { Central/South } \\
\text { America }\end{array}$ & GTCCTT & GTATTC & CAAGCA & $X^{d}$ \\
\hline I & Uganda & GTCTTT & GTACTC & CAAACA & TTTAAA \\
\hline 2 & Papua New Guinea & GTCCTT & GTATTC & CAAGCA & TTTAGA \\
\hline 3 & Papua New Guinea & GTCCTT & GTATTC & CAAGCA & TTTAGA \\
\hline 4 & Ivory Coast & GTCTTT & GTATTG & CAAACA & $X^{d}$ \\
\hline 5 & Papua New Guinea & GTCCTT & GTATTC & CAAGCA & TTTAGA \\
\hline 6 & Papua New Guinea & GTCCTT & GTATTC & CAAGCA & $X^{d}$ \\
\hline 7 & Tanzania & GTCCTT & GTATTC & CAAGCA & TTTAGA \\
\hline 8 & Tanzania & GTCCTT & GTATTC & CAAGCA & TTTAAA \\
\hline 9 & Papua New Guinea & GTCCTT & GTATTC & CAAGCA & $X^{d}$ \\
\hline 10 & Solomon Islands & GTCCTT & GTATTC & CAAGCA & TTTAGA \\
\hline 11 & Ghana & GTCTTT & GTATTG & CAAACA & TTTAAA \\
\hline 12 & Papua New Guinea & GTCCTT & GTATTC & CAAGCA & TTTAGA \\
\hline 13 & Papua New Guinea & GTCTTT & GTAGTC & CAAACA & TTTAGA \\
\hline 14 & Papua New Guinea & GTCTTT & GTATTG & CAAGCA & TTTAAA \\
\hline 15 & Pakistan & GTCCTT & GTATTC & CAAGCA & TTTAGA \\
\hline 16 & Papua New Guinea & GTCCTT & GTATTC & CAAGCA & TTTAGA \\
\hline 17 & Papua New Guinea & GTCCTT & GTATTC & CAAGCA & TTTAGA \\
\hline 18 & Kenya & GTCTTT & GTAGTC & CAAACA & TTTAAA \\
\hline 19 & Papua New Guinea & GTCCTT & GTATTC & CAAGCA & TTTAAA \\
\hline 20 & Papua New Guinea & $X^{d}$ & $X^{d}$ & $X^{d}$ & TTTAGA \\
\hline 21 & Togo & $X^{d}$ & $X^{d}$ & $X^{d}$ & TTTAAA \\
\hline 22 & Papua New Guinea & $X^{d}$ & $X^{d}$ & $X^{d}$ & TTTAAA \\
\hline 23 & Tanzania & $X^{d}$ & $X^{d}$ & $X^{d}$ & TTTAAA \\
\hline 24 & Zimbabwe & $X^{d}$ & $X^{d}$ & $X^{d}$ & TTTAAA \\
\hline 25 & Ghana & $X^{d}$ & $X^{d}$ & $X^{d}$ & TTTAAA \\
\hline CAMPe & SE Asia & $X^{d}$ & $X^{d}$ & $X^{d}$ & TTTAAA \\
\hline LE5e & Africa & $X^{d}$ & $X^{d}$ & $X^{d}$ & TTTAAA \\
\hline LF4e & Africa & $X^{d}$ & $X^{d}$ & $X^{d}$ & TTTAAA \\
\hline HB3e & $\begin{array}{l}\text { Central/South } \\
\text { America }\end{array}$ & $X^{d}$ & $X^{d}$ & $X^{d}$ & TTTAAA \\
\hline $7 \mathrm{G} 8 \mathrm{e}$ & $\begin{array}{l}\text { Central/South } \\
\text { America }\end{array}$ & $X^{d}$ & $X^{d}$ & $X^{d}$ & TTTAAA \\
\hline $\mathrm{Dd} 2^{\mathrm{e}}$ & SE Asia & $X^{d}$ & $X^{d}$ & $X^{d}$ & TTTAGA \\
\hline 2DIIe & SE Asia & $X^{d}$ & $X^{d}$ & $X^{d}$ & TTTAGA \\
\hline 2 Philippine isolates & SE Asia & $X^{d}$ & $X^{d}$ & $X^{d}$ & TTTAAA \\
\hline 30 Philippine isolates ${ }^{\mathrm{e}}$ & SE Asia & $X^{d}$ & $X^{d}$ & $X^{d}$ & TTTAGA \\
\hline
\end{tabular}

a The precise geographic origin of laboratory parasite strains is unclear in some instances

b Variable nucleotide positions for PfWARP are indicated in bold (GenBank: NC 004329 Region: 122 I 207... 1222079).

c Variable nucleotide positions for Pfs 28 are indicated in bold (GenBank: L25843).

d The symbol " $X$ " is used to indicate that the isolate was not tested.

e Theses isolates, laboratory strains and their geographic origin are cited as given in the paper by Hafalla et al [12].

10. Kaslow DC, Quakyi IA, Syin C, Raum MG, Keister DB, Coligan JE, McCutchan TF, Miller LH: A vaccine candidate from the sexual stage of human malaria that contains EGF-like domains. Nature 1988, 333:74-76.

11. Duffy PE, Kaslow DC: A novel malaria protein, Pfs28, and Pfs25 are genetically linked and synergistic as falciparum malaria transmission-blocking vaccines. Infect Immun 1997, 65:1109-1113.

12. Hafalla JC, Santiago ML, Pasay MC, Ramirez BL, Gozar MM, Saul A, Kaslow DC: Minimal variation in the Pfs28 ookinete antigen from Philippine field isolates of Plasmodium falciparum. Mol Biochem Parasitol 1997, 87:97-99.

13. Eisen D, Billman-Jacobe H, Marshall VF, Fryauff D, Coppel RL: Temporal variation of the merozoite surface protein-2 gene of Plasmodium falciparum. Infect Immun 1998, 66:239-246.

14. Kaslow DC, Quakyi IA, Keister DB: Minimal variation in a vaccine candidate from the sexual stage of Plasmodium falciparum. Mol Biochem Parasitol 1989, 32:101-104.

15. Tsuboi T, Kaslow DC, Gozar MM, Tachibana M, Cao YM, Torii M: Sequence polymorphism in two novel Plasmodium vivax ook- 
inete surface proteins, Pvs25 and Pvs28, that are malaria transmission-blocking vaccine candidates. Mol Med 1998, 4:772-782.

16. Ya-Ping S, Alpers MP, Povoa MM, Lal AA: Single amino acid variation in the ookinete vaccine antigen from field isolates of Plasmodium falciparum. Mol Biochem Parasitol 1992, 50: $179-180$.

17. Eisen DP, Saul A, Fryauff DJ, Reeder JC, Coppel RL: Alterations in Plasmodium falciparum genotypes during sequential infections suggest the presence of strain specific immunity. $\mathrm{Am} J$ Trop Med Hyg 2002, 67:8-16.

18. Hisaeda H, Collins WE, Saul A, Stowers AW: Antibodies to Plasmodium vivax transmission-blocking vaccine candidate antigens Pvs25 and Pvs28 do not show synergism. Vaccine 200I, 20:763-770.

19. Kaslow DC: Transmission-blocking vaccines. Chem Immunol 2002, 80:287-307.

20. Malkin EM, Durbin AP, Diemert DJ, Sattabongkot J, Wu Y, Miura K, Long CA, Lambert L, Miles AP, Wang J, Stowers A, Miller LH, Saul A: Phase I vaccine trial of Pvs25H: a transmission blocking vaccine for Plasmodium vivax malaria. Vaccine 2005, 23:3|3|-3|38.

Publish with Bio Med Central and every scientist can read your work free of charge

"BioMed Central will be the most significant development for disseminating the results of biomedical research in our lifetime. "

Sir Paul Nurse, Cancer Research UK

Your research papers will be:

- available free of charge to the entire biomedical community

- peer reviewed and published immediately upon acceptance

- cited in PubMed and archived on PubMed Central

- yours - you keep the copyright

Submit your manuscript here:

http://www.biomedcentral.com/info/publishing_adv.asp 